\title{
Regional Difference in the Organizational Commitment-Rewards Relationship in Vietnam
}

\author{
Keisuke Kokubun ${ }^{1}$ \\ ${ }^{1}$ International Economy and Work Research Institute, Osaka, Japan \\ Correspondence: Keisuke Kokubun, International Economy and Work Research Institute, 3-14 \\ Kitahama-Higashi, Chuo-ku, Osaka, 540-0031, Japan. Tel: 81-6-6943-9490. E-mail:kokubun@iewri.or.jp
}

Received: June 1, 2017

Accepted: July 5, 2017 Online Published: August 3, 2017

doi:10.5539/jms.v7n3p22

URL: http://doi.org/10.5539/jms.v7n3p22

\begin{abstract}
This study investigates the relationship between rewards and the organizational commitment (OC) of 5,522 employees who work for 5 Japanese companies in Vietnam focusing on the difference between Red River Delta (Hanoi and surrounding provinces) and South East (Ho Chi Minh City and surrounding provinces). Hierarchical regression analysis revealed that co-worker support had stronger influence on OC in Red River Delta than in South East. On the other hand, benefit satisfaction had stronger influence on OC in South East than in Red River Delta. Other rewards (i.e., fatigue, supervisor support and autonomy) were equally related with OC for both areas. These results mean that OC-rewards relationship differs between regions and indicate signs of increasing individualism among Vietnamese employees in more economically developed parts of the country. Discussions and implications concerning human resource management in Vietnam are offered.
\end{abstract}

Keywords: exploratory factor analysis, organizational commitment, Japanese companies, regional difference, rewards, Vietnam

\section{Introduction}

Since economic and political reforms under Đổi Mới launched in 1986, Vietnam has experienced rapid economic growth and development and transformed itself from one of the world's poorest nations to a lower middle-income country. Since 1990, Vietnam's GDP per capita growth has been among the fastest in the world, averaging 6.4 percent a year in the 2000s. Despite uncertainties in the global environment, Vietnam's economy remains resilient being supported by the country's fundamental drivers of growth, namely resilient domestic demand and export oriented manufacturing (World Bank, 2017).

Especially, foreign direct investment (FDI) is an important source of capital and economic growth as it provides a package of new technology, management expertise, finance and market access for the production of goods and services (Vuong \& Yokoyama, 2011). Vietnam has successfully attracted large volumes of FDI, sustaining levels of around 10-12 billion USD per year over the resent several years. Accordingly, foreign invested companies have played an increasingly important role in Vietnam economy: FDI sector exports reached 67 percent of the country's total exports in 2013, up from 47 percent in 2000; and foreign invested enterprises' share of the GDP increased to 18 percent from 13 percent over the same period (U.S. Department of State, 2014). Japanese firms in particular have been eager to increase manufacturing investment and continued to benefit from Vietnam's growth remaining one of the leading investors in Vietnam. Total accumulated number of projects and amount of capital of Japanese direct investment were 2,914 and 38,973.6 million USD in the end of 2015, which accounted for $14.5 \%$ and $13.8 \%$ of those of total FDI and became Vietnam's second largest source of foreign capital following the Republic of Korea (General Statistics Office of Vietnam, 2016). Vietnam was the third promising destination for overseas operation by Japanese manufacturing companies over medium term, just behind China and India, and the fifth over the long term following India, China, Russia and Brazil (Japan Bank for International Cooperation, 2008).

However, $66.6 \%$ of Japanese companies answer that "increase of employment cost" is an obstacle for investment to this country (Japan External Trade Organization, 2014). Besides, employees' voluntary turnover rate is high, $12.7 \%$ for multinational corporations (MNC) and $17.2 \%$ for local companies in 2014 respectively (Mercer \& Talentnet Corporation, 2015). Then the managers who intend to manage subsidiaries in Vietnam may have come to the stage where they should consider not only of using low cost labor force but of how to utilize talented 
employees truly necessary for the company. Furthermore, as well as most other countries in the world, Vietnam has not developed impartially; i.e., economic level is much different between regions. Especially, the gap is significant between the two most developed areas, i.e., Red River Delta (Hanoi and surrounding provinces) and South East (Ho Chi Minh City and surrounding provinces), and others. Besides, there are a number of differences between these two advanced regions. For example, in 2011 there were 2,609 FDI enterprises for which 613,126 employees work in Red River Delta which account for $29.1 \%$ and $24.0 \%$ of total number of FDI enterprises and employees in Vietnam, respectively. These figures were much smaller than those of South East: 5,332 FDI enterprises and 1,535,376 employees account for $59.2 \%$ and $60.2 \%$ of total number of FDI enterprises and employees in Vietnam, respectively. Likewise, accumulated number of projects and amount of registered capital (million USD) were 6,186 (30.8\%) and 72,258 (25.6\%) in Red River Delta and 10,686 (53.2\%) and 122,545 (43.5\%) in South East, respectively (the figures in parentheses are the shares in Vietnam total). Accordingly, there is more than $10 \%$ difference in monthly average income per capita between regions: 3,265,000 VND in Red River Delta whereas 4,125,000 VND in South East in 2014 (General Statistics Office of Vietnam, 2014; 2016; 2016).

These differences are considered to be engendering the gaps on people's awareness of and attitudes towards the work and workplaces between regions. However, there is not enough accumulation of research about this theme. In this situation, it is necessary to research how these regions are different each other so that companies can acquire hints to reduce their employee turnover rates or attract the best employees in Vietnam grasping the characteristics of these regions. So, this study analyzes antecedents of organizational commitment (OC) and difference between employees in Red River Delta and South East who are employed by Japanese firms. OC is defined as the employees' state of being committed to assist in the achievement of the organization's goals, and involves the employees' levels of identification, involvement and loyalty (Caught, Shadur, \& Rodwell, 2000). The reason why the researcher focuses on the antecedents of OC is because OC is seen as a prime explanation for why some desire to remain employed while others do not (Allen \& Meyer, 1990; Mowday, Porter, \& Steers, 1982; Peyyer, Jordan, Firms, \& Travaglione, 2010; Steers, 1977) or why some have a high work performance while others do not (Meyer, Stanley, Herscovitch, \& Topolnytsky, 2002; Phipps, Prieto, \& Ndinguri, 2013). OC is also known to be related with the corporate innovation and creativity (Hou, Gao, Wang, \& Yu, 2011; Jafri, 2010).

Although the gap would be more significant between these developed areas and other less developed areas, we in this paper compare these two developed regions only, namely, relatively less developed Red River Delta and more developed South East due to limited data availability in other regions. However, the researcher considers that we may become to predict how the other more backward areas are different from these more developed areas and how they will change in future by extrapolating the findings of this research. This study may also provide an implication to the government on how to reduce domestic economic gaps between regions to attain sustainable development because previous study showed that greater equality of income increased the duration of countries' economic growth spells more than free trade, low government corruption, foreign investment, or low foreign debt (Berg \& Ostry, 2011). Accordingly, it may not be unreasonable to assume that if Vietnamese laborers in corporations in backward regions could have higher OC, the economies would show higher performances by retaining high-quality employees in particular workplaces for a long period, which enables smoother technological transfer, knowledge sharing and organizational growth in a corporation (Chiang, Han, \& Chuang, 2011; Neyestani, Piran, Nasabi, Nosrati, \& Maidanipour, 2013), and accordingly would promote balanced and long-standing national development.

\section{Literature Review}

\subsection{Organizational Rewards in Vietnam}

The achievement of an organization does not only rely on how the organization utilizes its human capitals and competencies but also on how it incites commitment to the organization (Beukhof, De Jong, \& Nijhof, 1998). Hence, there is growing evidence to suggest that organizations can enhance the commitment of their workforce through the provision of organizational rewards (Newman, Thanacoody, \& Hui, 2011). The social exchange theory supposes that when an individual is happy with the rewards provided by their organization, they will reciprocate by developing positive attitudes towards their organization such as higher levels of commitment (Haar \& Spell, 2004). Besides, it was shown that enhancement of OC brings higher productivity and lower turnover intention in the West (e.g., Meyer, et al., 2002). However, despite tremendous research on OC, there is little research on OC and its antecedents in non-Western countries and Vietnam in particular. Furthermore, it is unclear how different categories of organizational rewards might influence organizational commitment in different regions in Vietnam. 
Several studies conducted in Vietnam also show that $\mathrm{OC}$ is strongly related to the employee's intention to leave or stay with the organization and it plays a vital role to strengthen the organization growth (Hai, 2012; Pham \& Pham, 2016). In addition, another study has indicated a strong link between OC and employee performance (Than, Pham, \& Pham, 2016). The antecedents significantly correlated with OC in previous study in Vietnam setting were: autonomy or discretional power (Pham \& Pham, 2016); financial compensation (Pham \& Pham, 2016); support from supervisors/colleagues (Nguyen, Mai, \& Nguyen, 2014; Pham \& Pham, 2016), etc. From a different viewpoint, Than, Pham and Pham (2016) indicated that job stress influenced employee performance. Following these pieces of research, this paper supposes five rewards as the antecedents of OC. They are: autonomy; benefit satisfaction; fatigue; supervisor support; and co-worker support.

These rewards are sometimes classified into three groups: i.e., intrinsic, extrinsic and social rewards. In previous research, intrinsic rewards comprised autonomy, extrinsic rewards included benefit satisfaction and fatigue, and social rewards contained supervisor support and co-worker support (e.g., Kokubun, 2017). Porter and Lawler (1968) defined intrinsic rewards as the satisfaction that a person derives from doing the job and extrinsic rewards as tangible benefits obtained as a result of doing the job, such as pay and promotions. On the other hand, according to Mottaz (1985), social rewards refer to those that are derived from interpersonal relationships with colleagues and supervisors. As there is little research in this field in Vietnam, the researcher pick up China as a substitute to estimate the relation between OC and rewards in this research because China shares with Vietnam some similarities not only on political features (e.g., Socialism, Confucianism), geographical positions, economic stages, etc. but also on human matters such as mutual respect, face-saving, and politeness which dominate all levels of the relationship among organizational members (Nguyen, 2002), and there are more stocks of research than in most other Asian countries. Previous work in the West and China are summarized as: (i) intrinsic rewards have a greater impact on $\mathrm{OC}$ of employees in the West than extrinsic or social rewards (Eby, Freeman, Rush, \& Lance, 1999; Malhotra, Budhwar, \& Prowse, 2007; O'Reilly \& Caldwell, 1980); and (ii) extrinsic and social rewards have a greater impact on OC of Chinese employees than intrinsic rewards (Miao, Newman, Sun, \& Xu, 2013; Newman \& Sheikh, 2012).

As it was found by Hofstede (1980) that culture of a country changes as its economy develops, difference between "(i)" and "(ii)" might be attributed not only to geographical features such as the West and the East but also to economic stages on which each country is placed. Various researchers (e.g.,Triandis, 1995; Hofstede, 2001) have argued that individualism-collectivism is related to societies' level of wealth and economic development with a shift from collectivism to individualism. In empirical research, actually, a strong positive correlation between economic affluence and the level of individualism was observed (Basabe \& Ros, 2005; Fischer \& Mansell, 2009). Here, Boyacigiller \& Adler (1991) argue that the commitment of employees with collectivist values may arise from ties with managers, owners, and co-workers, whereas the commitment of employees with an individualist orientation may be due to the job itself or the compensation system. If these assertions are true, the reason of "(i)" might be attributed as follows: as Western countries are overall more developed than others, employees are more individualistic and intrinsic rewards are accordingly more important for OC. On the other hand, for "(ii)", it may be assumed that: as China is less developed than Western countries, employees are less individualistic and social rewards are accordingly more important for OC. The reason why extrinsic rewards are more important for OC of employees in China in spite of its collectivistic culture will be that the economy of China is still in transition and most employees have to work for resources for subsisting.

\subsection{Moderating Role of Region}

However, compared to such research undertaken cross nationally, little attempt has been made to explore intra-national divergences. A little empirical evidence of intra-national study in China setting suggests that individualism could be increasing (Yan, 2009) and such a trend is likely to be most evident in more economically developed parts of the country (Ralston et al., 2008) although it has been argued that Chinese culture is largely collectivistic. In line with these pirces of research, the present study focuses on OC at the sub-national level within Vietnam, a nation where such differences are well documented. Reflecting the limitations of cross-cultural OC studies, the chief objectives of this paper are to explore whether patterns of OC differ according to regional differences in the level of economic development within Vietnam and the extent to which these might indicate signs of increasing individualism among Vietnamese employees. Such a trend is predicted to be most evident in more economically developed parts of the country. This leads us to the following hypotheses:

\subsubsection{Extrinsic Rewards}

Hypothesis 1: Relationship between benefit satisfaction and OC is positively stronger for South East than Red River Delta. 
Hypothesis 2: Relationship between fatigue and OC is negatively stronger for South East than Red River Delta.

\subsubsection{Social Rewards}

Hypothesis 3: Relationship between supervisor support and OC is positively stronger for Red River Delta than South East.

Hypothesis 4: Relationship between co-worker support and OC is positively stronger for Red River Delta than South East.

\subsubsection{Intrinsic Rewards}

Hypothesis 5: Relationship between autonomy and OC is positively stronger for South East than Red River Delta.

The correspondence of these three rewards to five subdivided rewards was adopted from previous research (e.g., Kokubun, 2017). Among them, Hypothesis 1 to 2 are in line with the assertion that economic development promotes individualism (Hofstede, 2001) and that the commitment of employees with an individualist orientation may be due to the job itself or the compensation system (Boyacigiller \& Adler, 1991). Although these hypotheses contradict with the findings of previous research: extrinsic rewards are more strongly associated with $\mathrm{OC}$ in a collectivistic nation (i.e., China) than in individualistic nations (i.e., the West) due to the huge economic gaps between them, the researcher considers that the economic difference between Red River Delta and South East is not much significant to necessitate taking into account the effect of work for subsisting in the analysis. Hypothesis 3 to 5 are in line with the results of previous research in China and the West as described above: i.e., the former (more backward area) is stronger in social rewards whereas the latter (more developed area) is stronger in intrinsic rewards in relation with OC, respectively. More comprehensively, we are lead to the following hypotheses:

Hypothesis 6: Extrinsic rewards more contribute to forming OC in South East than in Red River Delta.

Hypothesis 7: Social rewards more contribute to forming OC in Red River Delta than in South East.

Hypothesis 8: Intrinsic rewards more contribute to forming OC in South East than in Red River Delta.

Off course, Vietnamese culture may not be explained individualism-collectivism axis only. It is fully considerable that other important cultural characteristics such as "high power distance" (Hofstede, 1980) or some kind of friction which is generated in the process of socialization of peasants into industrial laborers with regularity and discipline (Kerr, Dunlop, Harbison, \& Myers, 1960; Landes, 1969; Thompson, 1967) may affect these regional differences, too. However, as most previous research focuses on this individualism-collectivism axis, this paper tentatively follows this contrast here and is going to discuss the reason of possible differences between hypotheses and results in the latter part of this paper.

Accordingly, we propose following model (Figure1):

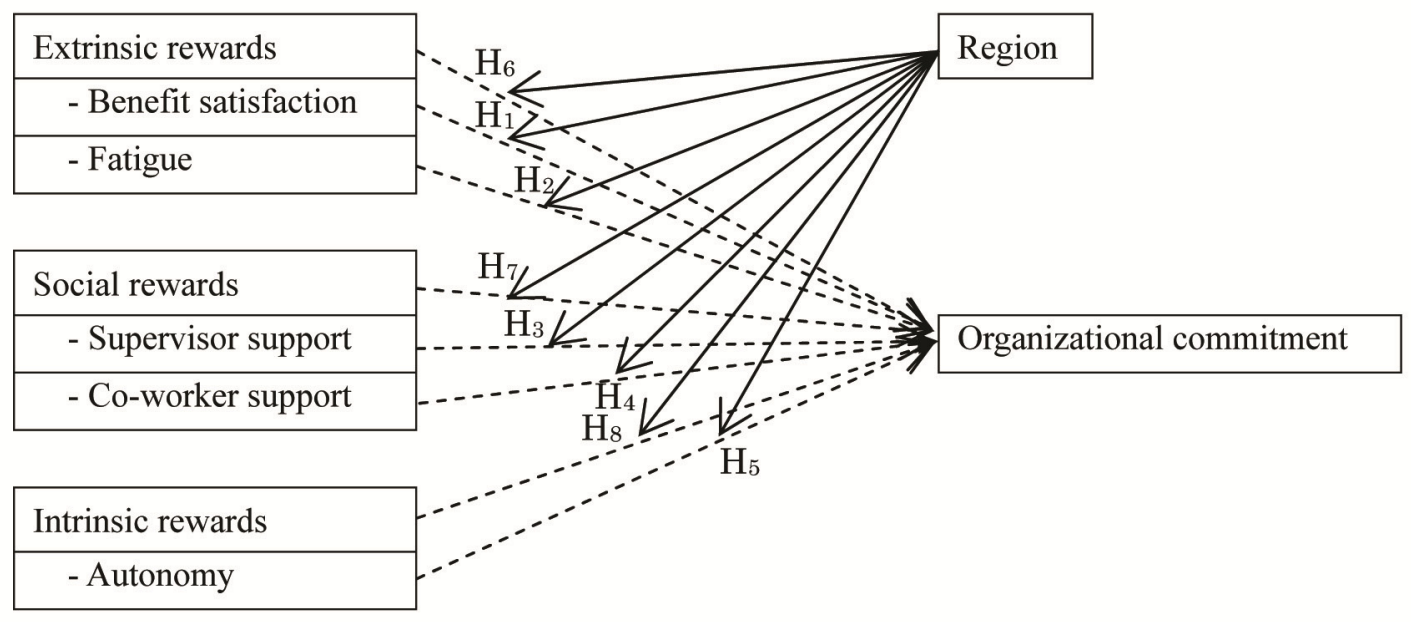

Note. $\longrightarrow$ : Moderating effect of region (Hypothesis 1 to 8)

Figure 1. The moderating effect of region on the organizational commitment-rewards relationship 


\subsection{Cultural Effect of China}

Before proceeding to concrete analyses, it may be better to review characteristics of the Vietnamese culture as members of a culture will have similar sets of preferences built into how they view the world (Hofstede, 2001). Vietnam has been affected by many countries economically and culturally. Especially, China has had a significant influence on Vietnam since Confucian traditionalism first came to Vietnam in 111 BCE by the Chinese colonization (Zhu, 2003, p. 254). Accordingly, the Vietnamese culture is described similarly with Chinese one as having large power distance, high collectivism, maintaining face, etc. (Nguyen, 2002; Ralston, Nguyen, \& Napier, 1999; Truong \& Nguyen, 2002). Among them, high collectivism characteristic of Vietnamese culture is reflected in values associated with the Vietnamese kinship system, where the parent-children relationship is viewed by the Vietnamese as basic to social life and thus most Vietnamese retain very close ties with their families. Such familial style is also widely accepted in Vietnamese enterprises: The bosses used to treat their company as a big family and often showed a parental concern for their employees. Accordingly, the typical management style in Vietnam is said to be paternalistic, authoritarian and familial (Quang \& Vuong, 2002, pp. 52-53). Furthermore, such superior-subordinate relationship is not limited within the organization; it is extended to the life outside the organizations as well (Nguyen, 2002).

However, these influences from China is said to be stronger in Red River Delta than in South East. On the other hand, the other kind of influences typically from the United States and Western countries through history of trade and colonization is said to be more influential in South East (Engholm, 1995; Ralston, Holt, Terpstra \& Yu, 1997). Furthermore, in the transition toward a market economy, there is high interest among younger managers, pioneered by those in FDI companies, to adopt and practice a participative style of management (Quang \& Vuong, 2002, p. 40). Besides, previous research reveals that Vietnamese nowadays become more individualistic than before as a result of rapid industrialization (Hoang, 2008). Such a new trend is considered to be stronger in South East than in Red River Delta taking account the difference in the volume of FDI and income levels between regions as described above.

\subsection{Japanese Companies' HRM Performance in Vietnam}

As we suppose in this paper that rewards are related with OC in Japanese companies in Vietnam, let us review what local employees think about Japanese companies before proceeding analyses. The Japanese manufacturing workplace has been characterized by commitment, loyalty and lower rates of turnover, absenteeism and industrial conflict along with high levels of productivity and product quality (Colignon, Usui, \& Kerbo, 2007). Besides, it has been argued that elements of Japanese management, such as secure employment or an emphasis on seniority, are still strongly present in Japanese overseas subsidiaries, and that such practices may even be more appropriate for countries that are developing economically (Wasti, 1998). However, in contrast, previous survey conducted in China has indicated that Japanese companies do not rank among the most popular employers, and are even frequently named as those that people would least want to work for (Zhang, 2003). Likewise, Yu \& Meyer-Ohle (2008) revealed that Chinese employees who worked for Japanese companies had more complaints than those who worked for Western companies in the areas of lack of privacy, process orientation (less flexible and less results-oriented work), long working hours and overtime, low remuneration, inadequate career development, etc. In Vietnam setting, for instance, Toyota (2015) argues that Japanese companies are less competitive in payment schemes especially for manages and skilled employees with paying them two to three times lower amount than those of the Western and South Korean companies.

From a different viewpoint, an empirical survey by Shiraki (2012) revealed that Japanese managers in East Asian countries received poorer evaluations from their subordinates than local managers did especially for job performing ability, leadership and capability for managing subordinates. Besides, such differences are more significant in original members of ASEAN countries (i.e., Thailand, Malaysia, Indonesia and Philippines) than in China, indicating that Japanese-led HRM is likely to become weaker in its effect as an economy experiences longer period of industrialization and employees become to require more sensitive cares from the management. From these findings, HRM of Japanese companies may not be fully effective for enhancing OC of employees especially in more developed areas where people are more individualistic and acquisitive, although may more or less be effective in less developed areas where people are more collectivistic and pastoral. In other words, Japanese companies in Vietnam may face some barriers to make it hard to provide employees appropriate support which could be perceived as the rewards worth reciprocating, especially in more developed areas.

\section{Methods}

\subsection{Participants}

We sent questionnaires to employees in 5 Japanese companies in Vietnam. We purposely selected Japanese 
companies in Vietnam instead of other kinds, such as state-owned or other private companies as they have a different set of HRM practices and many organizational variables would not be eligible for legitimate comparison with Japanese counterparts. 12,000 questionnaires were distributed via the HR department of participant companies. The participation was basically compulsory. With a promise to present the summary results, the HR department of each firm administered the questionnaires by distributing and collecting completed questionnaires. Each respondent was requested to put the completed questionnaire into an envelope that the researcher provided along with the questionnaire and seal it for him/her self to guarantee complete anonymity. Overall, 10,786 surveys were collected, reflecting a response rate of $89.9 \%$. However, in this analysis, we eliminated 7,839 surveys due to missing values (3,374 surveys) or inappropriate characteristics such as contract workers, Japanese expatriates, etc. (4,465 surveys). Consequently, the final samples comprised 2,947 Vietnamese participants. Among them, 583 participants working for a company are from South East and the other 2,364 participants working for 4 companies are from Red River Delta. Other demographic information of the participants is shown in tables of Appendix A.

\subsection{Measures}

The questions are obtained from Kokubun (2006), in which OC was correlated with various rewards in Malaysian setting. Recent research by Kokubun $(2017 ; 2017$; 2017) confirmed such correlations in setting of Thailand, Malaysia and China using the same questions, too. Accordingly, the researcher expects the similar association between the variables of reward and OC described below because these countries and Vietnam share similarities in geographical and cultural spheres (e.g., collectivism, high-power distance, etc. Cf. Hofstede, 1980). They are measured on a five-point scale. The original questionnaire was developed in English and then translated into Vietnamese. To ensure the accuracy of the translation, the questionnaire was then translated back.

\subsubsection{Benefit Satisfaction}

Benefit satisfaction was measured on a three-item scale. The alpha reliability was 0.761 for Red River Delta and 0.691 for South East.

\subsubsection{Fatigue}

Fatigue was measured on a three-item scale. The alpha reliability was 0.821 for Red River Delta and 0.790 for South East.

\subsubsection{Supervisor Support}

Supervisor support was measured on a five-item scale. The alpha reliability was 0.874 for Red River Delta and 0.847 for South East.

\subsubsection{Co-worker Support}

Co-worker support was measured on a four-item scale. The alpha reliability was 0.812 for Red River Delta and 0.798 for South East.

\subsubsection{Autonomy}

Autonomy was measured on a three-item scale. The alpha reliability was 0.655 for Red River Delta and 0.587 for South East.

\subsubsection{Organizational Commitment}

Five items were used to measure OC. The alpha reliability was 0.788 for Red River Delta and 0.756 for South East.

As observed above, the alpha reliability ranged from 0.587 to 0.874 , which suggested that the specified indicators are sufficient for use (Nunnally, 1978).

\subsubsection{Control Variables}

Several demographic variables were included to control for individual differences. Answered figures without any conversion were used for age and organizational tenure. Sample dummy shows South East or Red River Delta. Gender, university graduate/others, turnover experience, marital status, indirect/direct department, managerial/non-managerial position were also measured. Three dummy variables were created to control for the four different companies in Red River Delta.

\subsection{Analysis Tool}

The hierarchical regression analysis was used in this study to assess the influence of rewards on OC and the moderation role of region in the rewards-OC relationship. This tool is considered appropriate because it enables 
an understanding of the absolute contributions of the predictor variables to OC (Cohen \& Cohen, 1975).

\section{Results}

We conducted an exploratory factor analysis of all items (except control variables) to examine measurement invariance between Red River Delta and South East. The results of the factor analysis with varimax rotation are presented in Table 1, confirming a six-factor solution for all the items of benefit satisfaction, fatigue, supervisor support, co-worker support, autonomy and OC. The factor structure was the same for Red River Delta and South East; therefore, we are convinced that both Red River Delta and South East employees ascribed the same meanings to the scale items used in the current study (Milfont \& Fischer, 2010). For reference, applying another side of the same reasoning, the researcher does not use the items "training" and "role clarity" (Kokubun, 2017; 2017 ; 2017) to which the parties did not ascribe the same meanings according to the result of exploratory factor analysis in this research to prevent multicollinearity with other variables.

Descriptive statistics for both Red River Delta and South East are presented in Table 2. Since correlation analysis which provides information about the relationship between dependent and independent variables did not present significant relationships between variables, where correlation coefficients ranged from 0.002 to 0.790 for all the pairs of variables and 0.190 to 0.568 for pairs within main variables and variable redundancy did not appear to be of concern (Nunnally, 1978), a hierarchical multiple regression analysis was conducted to test our hypotheses in Table 3. We entered the control variables, including sample variable ( 1 for South East and 0 for Red River Delta), in Step 1 and main effects of benefit satisfaction, fatigue, supervisor support, co-worker support, autonomy in Step 2. In Step 3, we entered interaction terms of sample variable with main effects for the entire sample to test regional moderation. Variables forming the interaction term were entered to minimize multicollinearity among the interaction terms and their components (Aiken \& West, 1991). In addition, we conducted separate regression analysis using Red River Delta and South East data. All regression results are presented in Table 3.

Step 1 presents the results when only the control variables are included in the regression to predict OC. Six out of nine demographic variables were found to influence OC. Among them, age, marital status, indirect department, position and sample were positively and gender was negatively related to OC. That means that employees of aged, married, indirect, higher position, South East and women tend to have higher OC than those of younger, single, direct, lower position, Red River Delta and men.

Step 2 presents the results when all the five reward variables are added to the regression. Fatigue is negatively and the other four reward variables are positively associated to the regression significantly $(p<0.01)$.

At Step 3, the relationship between benefit satisfaction and OC was moderated by the sample, showing that their relationship was stronger in South East than in Red River Delta $(\beta=0.11, p<0.10)$. In other words, employees' OC was more affected by benefit satisfaction in South East compared with in Red River Delta. However, on the other hand, the relationship of co-worker support with OC was weaker in South East than in Red River Delta $(\beta=-0.15, p<0.10)$, which suggests that co-worker support is less important in forming OC in South East than Red River Delta. The significant results of these moderation tests are consistent with Hypothesis 1 and 4 . However, the relationships of other variables with OC showed no significant difference between Red River Delta and South East, inconsistent with Hypothesis 2, 3 and 5.

In separate regression analysis using Red River Delta and South East data, we entered the control variables in Step 1, and main effects of benefit satisfaction, fatigue, supervisor support, co-worker support, autonomy in Step 5. In Step 2 to 4, main effects were separately entered by the kind of rewards (extrinsic, social and intrinsic rewards) to test their comparative importance. All the five reward variables were significantly associated with OC when they were entered separately in Step 2 to $4(p<0.05)$. However, both fragments of social rewards were not significantly associated in South East data when they were entered together with other kind of rewards in Step 5 suggesting relatively low importance for OC. Observing adjusted $\mathrm{R}^{2}$, extrinsic, social and intrinsic rewards explained $17 \%, 21 \%, 23 \%$ of additional variance in OC respectively in Red River Delta data. On the other hand, these figures were $16 \%, 10 \%$ and $15 \%$ in South East data. These imply that all of three types of reward are important for OC in both regions, although social rewards are more important than extrinsic rewards in Red River Delta while extrinsic rewards are more important than social rewards in South East, supporting Hypothesis 6 and 7. However, these figures show at the same time that intrinsic rewards are as important as the more important one of two another rewards: namely, intrinsic rewards are as important as social rewards in Red River Delta and extrinsic rewards in South East in forming OC respectively, contradicting Hypothesis 8.

To sum up, Hypothesis 1, 4, 6 and 7 were supported, while Hypothesis 2, 3, 5 and 8 were rejected. In other words, employees' OC was more correlated with extrinsic rewards (especially with benefit satisfaction) than 
social rewards in South East and more correlated with social rewards (especially with co-worker support) than extrinsic rewards in Red River Delta. However, we may not overlook the result that OC was correlated with intrinsic rewards as significantly as extrinsic rewards in South East and social rewards in Red River Delta, and accordingly there was no marked comparative difference in intrinsic rewards-OC relationship between regions.

\section{Discussion and Implications for Theory and Practice}

The objective of the present study was to investigate the difference between Red River Delta (Hanoi and surrounding provinces) and South East (Ho Chi Minh City and surrounding provinces) in antecedents of the organizational commitment (OC) of employees working in the Japanese companies in Vietnam. Our findings demonstrate that all the rewards (i.e., benefit satisfaction, fatigue, supervisor support, co-worker support, autonomy) engendered higher levels of OC. This is in line with previous research (e.g., Kokubun, 2017; 2017; 2017) and indicates there are many rewards to enhance Vietnamese OC. However, we found the two differences between Red River Delta and South East.

Table 1. Results of exploratory factor analysis

\begin{tabular}{|c|c|c|c|c|c|c|c|c|c|c|c|c|}
\hline \multirow[b]{2}{*}{ Items } & \multicolumn{6}{|c|}{ Red River Delta } & \multicolumn{6}{|c|}{ South East } \\
\hline & $\begin{array}{c}\text { Benefit } \\
\text { satisfactio } \\
\text { n }\end{array}$ & Fatigue & $\begin{array}{l}\text { Superviso } \\
\mathrm{r} \text { support }\end{array}$ & $\begin{array}{c}\text { Co- } \\
\text { workers } \\
\text { support }\end{array}$ & Autonomy & $\begin{array}{l}\text { Organizati } \\
\text { onal } \\
\text { commitm } \\
\text { ent }\end{array}$ & $\begin{array}{c}\text { Benefit } \\
\text { satisfactio } \\
\text { n }\end{array}$ & Fatigue & $\begin{array}{l}\text { Superviso } \\
\text { r support }\end{array}$ & $\begin{array}{l}\text { Co- } \\
\text { workers } \\
\text { support }\end{array}$ & Autonomy & $\begin{array}{c}\text { Organizati } \\
\text { onal } \\
\text { commitm } \\
\text { ent }\end{array}$ \\
\hline Welfare system of the company. & 0.699 & -0.149 & 0.094 & 0.196 & 0.082 & 0.177 & 0.77 & -0.05 & 0.08 & 0.20 & 0.19 & 0.14 \\
\hline Holidays and working hours. & 0.641 & -0.208 & 0.172 & 0.183 & 0.156 & 0.147 & 0.65 & -0.22 & 0.15 & 0.12 & 0.03 & 0.17 \\
\hline Amount of my salary or wage. & 0.500 & -0.230 & 0.246 & 0.182 & 0.070 & 0.205 & 0.35 & -0.15 & 0.22 & 0.14 & 0.00 & 0.22 \\
\hline I often feel exhausted. & -0.130 & 0.928 & -0.126 & -0.095 & -0.074 & -0.110 & -0.12 & 0.85 & -0.15 & -0.05 & -0.03 & -0.18 \\
\hline I feel exhausted when I wake up in the morning. & -0.174 & 0.664 & -0.090 & -0.099 & -0.075 & -0.104 & -0.07 & 0.69 & -0.09 & -0.03 & -0.10 & -0.08 \\
\hline After finishing my work, I feel exhausted. & -0.119 & 0.649 & -0.111 & -0.089 & -0.066 & -0.097 & -0.11 & 0.64 & -0.09 & -0.13 & -0.08 & 0.00 \\
\hline My boss/supervisor is trustful. & 0.098 & -0.123 & 0.771 & 0.187 & 0.178 & 0.154 & 0.13 & -0.10 & 0.79 & 0.21 & 0.12 & 0.07 \\
\hline My boss/supervisor treats employees fairly. & 0.174 & -0.118 & 0.757 & 0.239 & 0.159 & 0.137 & 0.03 & -0.15 & 0.68 & 0.24 & 0.10 & 0.17 \\
\hline My boss/supervisor deals with employees' complaints effectively. & 0.187 & -0.112 & 0.673 & 0.246 & 0.188 & 0.124 & 0.14 & -0.10 & 0.66 & 0.28 & 0.06 & 0.07 \\
\hline My boss/supervisor trusts workers. & 0.095 & -0.112 & 0.653 & 0.177 & 0.179 & 0.131 & 0.15 & -0.12 & 0.65 & 0.19 & 0.19 & 0.12 \\
\hline Evaluation by my co-workers and subordinates. & 0.139 & -0.124 & 0.243 & 0.760 & 0.169 & 0.120 & 0.07 & -0.08 & 0.19 & 0.79 & 0.03 & 0.14 \\
\hline Relationship with my co-workers and subordinates. & 0.115 & -0.150 & 0.316 & 0.684 & 0.166 & 0.115 & 0.09 & -0.08 & 0.25 & 0.73 & 0.14 & 0.06 \\
\hline Ability of my co-workers and subordinates. & 0.252 & -0.071 & 0.157 & 0.559 & 0.143 & 0.149 & 0.12 & -0.07 & 0.21 & 0.60 & 0.04 & 0.08 \\
\hline Human relationship at my working place. & 0.215 & -0.083 & 0.214 & 0.447 & 0.231 & 0.187 & 0.22 & -0.05 & 0.21 & 0.49 & 0.20 & 0.04 \\
\hline My own ideas are fully utilized in my work. & 0.024 & -0.050 & 0.179 & 0.180 & 0.556 & 0.095 & 0.08 & -0.05 & 0.12 & 0.13 & 0.56 & 0.16 \\
\hline I can fully utilize my talent/ability in my work. & 0.149 & -0.074 & 0.267 & 0.145 & 0.521 & 0.266 & 0.03 & 0.03 & 0.26 & 0.11 & 0.44 & 0.33 \\
\hline I carry out my work by observing and planning it by myself. & 0.151 & -0.117 & 0.155 & 0.167 & 0.488 & 0.210 & 0.06 & -0.14 & 0.05 & 0.05 & 0.54 & 0.09 \\
\hline I want to continue my present work. & 0.114 & -0.123 & 0.154 & 0.135 & 0.132 & 0.821 & 0.11 & -0.09 & 0.06 & 0.05 & 0.13 & 0.75 \\
\hline On the whole, I am satisfied with my present work. & 0.226 & -0.164 & 0.174 & 0.137 & 0.214 & 0.652 & 0.12 & -0.08 & 0.14 & 0.13 & 0.12 & 0.76 \\
\hline I have strong will to work hard in this company. & 0.201 & -0.104 & 0.139 & 0.177 & 0.230 & 0.497 & 0.19 & -0.09 & 0.10 & 0.08 & 0.21 & 0.50 \\
\hline
\end{tabular}

Table 2. Descriptive statistics and correlations

\begin{tabular}{|c|c|c|c|c|c|c|c|c|c|c|c|c|c|c|c|c|c|c|}
\hline & \multicolumn{2}{|c|}{ Mean } & \multicolumn{2}{|c|}{ SD } & \multicolumn{14}{|c|}{ South East Red River Delta } \\
\hline & $\begin{array}{c}\text { Red River } \\
\text { Delta }\end{array}$ & South East & $\begin{array}{c}\text { Red River } \\
\text { Delta }\end{array}$ & South East & 1 & 2 & 3 & 4 & 5 & 6 & 7 & 8 & 9 & 10 & 11 & 12 & 13 & 14 \\
\hline 1 Gender & 0.673 & 0.244 & 0.469 & 0.430 & 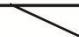 & $0.095^{* * * *}$ & $0.042^{* *}$ & $-0.035^{*}$ & $0.083^{* * * *}$ & $-0.123^{* * *}$ & $-0.078^{* * *}$ & $0.073^{* * * *}$ & $-0.132^{* * * *}$ & $0.126^{* * *}$ & 0.010 & 0.014 & $0.128^{* * *}$ & $-0.165^{* * * *}$ \\
\hline 2 Age & 28.623 & 25.942 & 4.879 & 4.110 & $0.312^{* * * *}$ & & $0.790^{* * * *}$ & $0.186^{* * * *}$ & $0.164^{* * *}$ & $0.378^{* * *}$ & $0.103^{* * * *}$ & $0.349^{* * * *}$ & $0.132^{* * * *}$ & $-0.148^{\text {**** }}$ & * $0.103^{* * *}$ & $0.092^{* * *}$ & $0.191^{* * * *}$ & $0.099^{\text {*** }}$ \\
\hline 3 Tenure & 6.217 & 3.106 & 3.786 & 2.948 & $0.173^{* * * *}$ & $0.675^{\mathrm{k} * \mathrm{k}}$ & & -0.033 & 0.001 & $0.386^{* * * *}$ & $-0.103^{\text {*k* }}$ & $0.295 * * *$ & $0.134^{* * *}$ & $-0.088^{* * *}$ & *0.065*** & $0.04 *$ & $0.163^{* * *}$ & $0.090^{* * * *}$ \\
\hline 4 University graduate & 0.159 & 0.136 & 0.365 & 0.343 & $0.289^{* * * *}$ & $0.369^{* * *}$ & $0.137^{* * *}$ & & $0.187^{* * *}$ & -0.022 & $0.432 * * *$ & $0.375 * * *$ & $0.111^{* * *}$ & $-0.182 * * *$ & $* 0.168 * * *$ & $0.153^{* * *}$ & $0.113^{* * *}$ & $0.041^{* *}$ \\
\hline 5 Turnover experience & 0.392 & 0.882 & 0.488 & 0.323 & $0.097^{* *}$ & $0.172^{* * *}$ & $0.217 * * *$ & $0.114^{* * *}$ & & 0.017 & $0.138^{* * * *}$ & $0.105^{* * * *}$ & $-0.044^{* *}$ & 0.002 & -0.017 & -0.007 & $0.052^{* *}$ & -0.026 \\
\hline 6 Marital status & 0.735 & 0.429 & 0.442 & 0.495 & $0.211^{* * *}$ & $0.461^{* * *}$ & $0.344 * * *$ & $0.103^{* *}$ & $0.081^{* *}$ & & $-0.041^{* *}$ & $0.111 * * *$ & $0.065^{* * *}$ & $-0.065 * * *$ & $*-0.006$ & 0.010 & $0.078 * * *$ & $0.127^{* * *}$ \\
\hline 7 Indirect department & 0.230 & 0.370 & 0.421 & 0.483 & $0.094^{* *}$ & $0.211^{* * *}$ & $0.117 * * *$ & $0.277^{* * *}$ & $0.083^{* *}$ & 0.039 & & $0.126^{* * * *}$ & 0.031 & $-0.160^{* * *}$ & * $0.149^{* * *}$ & $0.092^{* * *}$ & $0.050^{* *}$ & $0.061^{* * *}$ \\
\hline 8 Position & 0.060 & 0.077 & 0.237 & 0.267 & $0.105^{* *}$ & $0.269^{* * *}$ & $0.387^{* * *}$ & $0.167^{* * *}$ & 0.066 & $0.178^{* * *}$ & 0.018 & & $0.138 * *$ & $-0.092 * * *$ & * $0.159^{* * *}$ & $0.115^{* * *}$ & $0.176^{* * *}$ & $0.098^{* * *}$ \\
\hline 9 Benefit satisfaction & 3.228 & 3.139 & 1.081 & 0.946 & 0.058 & $0.099^{* *}$ & 0.057 & $0.092^{* *}$ & 0.063 & $0.106^{* *}$ & $0.074^{*}$ & 0.059 & & $-0.418^{* * *}$ & * $0.445 * * *$ & $0.497^{* * *}$ & $0.374^{* * *}$ & $0.474^{* * *}$ \\
\hline 10 Fatigue & 3.525 & 3.485 & 1.207 & 1.191 & -0.042 & $-0.218^{* * *}$ & $-0.106^{* *}$ & $-0.254^{* * *}$ & -0.038 & $-0.098^{* *}$ & $-0.179^{* * *}$ & $-0.080 *$ & $-0.308^{* * *}$ & & $-0.316^{* * *}$ & $*-0.317 * * *$ & $-0.258 * * *$ & $-0.330^{* * *}$ \\
\hline 11 Supervisor support & 3.116 & 3.197 & 1.242 & 1.229 & $0.079^{*}$ & $0.106^{* *}$ & 0.033 & $0.127^{* * *}$ & 0.012 & 0.020 & $0.149^{* * *}$ & $0.088 * *$ & $0.382 * * *$ & $-0.299 * * *$ & & 0.568 **** & $0.490 * * *$ & $0.430^{* * *}$ \\
\hline 12 Co-worker support & 3.480 & 3.594 & 0.895 & 0.837 & $0.129^{* * *}$ & $0.093^{* *}$ & $0.086 * *$ & $0.120^{* * * *}$ & $0.092 * *$ & $0.078 *$ & 0.038 & 0.058 & $0.374 * *$ & $-0.221^{* * * *}$ & $* 0.521 * * *$ & & $0.479^{* * * *}$ & $0.449^{* * *}$ \\
\hline 13 Autonomy & 2.861 & 3.142 & 1.091 & 1.070 & $0.194^{* * *}$ & $0.230^{* * *}$ & $0.164 * * *$ & $0.191^{* * *}$ & $0.146^{* * *}$ & $0.178^{* * *}$ & $0.094 * *$ & $0.162 * * *$ & $0.260 * * *$ & $-0.190^{* * *}$ & * 0.354 *** & $0.299^{* * *}$ & & $0.487^{* * *}$ \\
\hline 14 Organizational commitment & 3.862 & 3.807 & 1.165 & 1.104 & 0.034 & $0.096 * *$ & 0.046 & 0.010 & 0.026 & $0.151^{* * *}$ & 0.010 & 0.055 & $0.386 * * *$ & $-0.241^{* * *}$ & * $0.299 * * *$ & $0.262^{* * *}$ & $0.398 * * *$ & \\
\hline
\end{tabular}


Table 3. Result of hierarchical regression analyses

\begin{tabular}{|c|c|c|c|c|c|c|c|c|c|c|c|c|c|}
\hline \multirow[b]{2}{*}{ Variables } & \multicolumn{3}{|c|}{$\begin{array}{c}\text { Organizational commitment } \\
\text { (Red River Delta and South East, } \mathrm{n}=2,947 \text { ) }\end{array}$} & \multicolumn{5}{|c|}{$\begin{array}{l}\text { Organizational commitment } \\
\text { (Red River Delta, } \mathrm{n}=2,364 \text { ) }\end{array}$} & \multicolumn{5}{|c|}{$\begin{array}{l}\text { Organizational commitment } \\
\text { (South East, } \mathrm{n}=583 \text { ) }\end{array}$} \\
\hline & Step 1 & Step 2 & Step3 & Step 1 & Step 2 & Step 3 & Step 4 & Step 5 & Step 1 & Step 2 & Step 3 & Step 4 & $\begin{array}{l}\text { Step } 5 \\
\end{array}$ \\
\hline Gender & $-0.04 *$ & $-0.11^{* * *}$ & $-0.11^{* * *}$ & -0.04 & $-0.06 * *$ & $-0.09 * * *$ & $-0.11^{* * * *}$ & $-0.11 * * *$ & 0.00 & 0.00 & -0.02 & -0.05 & -0.03 \\
\hline Age & $0.09 * * *$ & 0.02 & 0.02 & $0.08 * *$ & 0.01 & 0.04 & 0.05 & 0.01 & 0.08 & 0.04 & 0.06 & 0.04 & 0.02 \\
\hline Tenure & -0.03 & -0.04 & -0.04 & -0.02 & 0.00 & -0.02 & -0.04 & -0.03 & -0.07 & -0.05 & -0.06 & -0.06 & -0.05 \\
\hline University graduate & 0.00 & $-0.07 * * *$ & $-0.06 * * *$ & 0.00 & $-0.05 * *$ & $-0.07 * * *$ & -0.03 & $-0.07 * * *$ & -0.03 & $-0.07 *$ & -0.05 & -0.07 & $-0.10 * *$ \\
\hline Turnover experience & 0.00 & 0.00 & 0.00 & -0.01 & 0.01 & 0.01 & -0.02 & 0.00 & 0.02 & 0.00 & 0.01 & -0.02 & -0.02 \\
\hline Marital status & 0.08 *** & $0.07^{* * *}$ & 0.07 *** & $0.06^{* * *}$ & 0.08 ** & $0.08 * * *$ & $0.04 * *$ & $0.066^{* * *}$ & $0.13^{* * *}$ & $0.10 * *$ & $0.13^{* * *}$ & $0.10^{* *}$ & $0.08 * *$ \\
\hline Indirect department & $0.05 * *$ & 0.00 & 0.00 & $0.07^{* * *}$ & 0.03 & 0.03 & $0.04 *$ & 0.02 & 0.00 & -0.03 & -0.02 & -0.01 & -0.04 \\
\hline Position & $0.07^{* * *}$ & 0.01 & 0.01 & $0.08 * * *$ & $0.04 * *$ & $0.05 * *$ & $0.03 *$ & 0.02 & 0.04 & 0.03 & 0.02 & 0.00 & -0.01 \\
\hline Sample & $0.29^{* * *}$ & 0.03 & 0.15 & & & & & & & & & & \\
\hline Company 1 (dummy) & $0.19^{* * *}$ & 0.05 & 0.05 & $0.22 * * *$ & $0.16 * *$ & 0.08 & $0.11 * *$ & 0.07 & & & & & \\
\hline Company 2 (dummy) & $0.25 * * *$ & 0.01 & 0.01 & $0.26 * * *$ & $0.12 *$ & 0.11 & 0.09 & 0.03 & & & & & \\
\hline Company 3 (dummy) & $0.41 * * *$ & $0.12 * * *$ & $0.12 * * *$ & $0.45 * * *$ & 0.17 *** & $0.24 * * *$ & $0.31 * * *$ & $0.14 * * *$ & & & & & \\
\hline \multicolumn{14}{|l|}{ Extrinsic rewards } \\
\hline Benefit satisfaction & & $0.19 * * *$ & $0.17 * * *$ & & $0.38^{* * *}$ & & & $0.17^{* * *}$ & & $0.34 * *$ & & & $0.24^{* * *}$ \\
\hline Fatigue & & $-0.08 * * *$ & $-0.07^{* * *}$ & & $-0.14 * *$ & & & $-0.07 * * *$ & & $-0.15 * *$ & & & $-0.11 * * *$ \\
\hline \multicolumn{14}{|l|}{ Social rewards } \\
\hline Supervisor support & & $0.09 * * *$ & $0.09 * * *$ & & & $0.24 * * *$ & & $0.09^{* * *}$ & & & $0.23^{* * *}$ & & 0.07 \\
\hline Co-worker support & & $0.11 * * *$ & $0.13 * * *$ & & & $0.30 * * *$ & & $0.13^{* * *}$ & & & $0.14^{* * *}$ & & 0.04 \\
\hline \multicolumn{14}{|l|}{ Intrinsic rewards } \\
\hline Autonomy & & $0.32 * * *$ & $0.32 * * *$ & & & & $0.50^{* * *}$ & $0.32 * * *$ & & & & $0.41^{* * *}$ & $0.30 * * *$ \\
\hline Sample×Benefit satisfaction & & & $0.11 *$ & & & & & & & & & & \\
\hline Sample $\times$ Fatigue & & & -0.02 & & & & & & & & & & \\
\hline SamplexSupervisor support & & & -0.04 & & & & & & & & & & \\
\hline Sample ×Co-worker support & & & $-0.15 *$ & & & & & & & & & & \\
\hline SamplexAutonomy & & & -0.04 & & & & & & & & & & \\
\hline $\mathrm{R}^{2}$ & 0.09 & 0.39 & 0.39 & 0.10 & 0.27 & 0.31 & 0.34 & 0.42 & 0.03 & 0.18 & 0.13 & 0.18 & 0.28 \\
\hline Adiusted $R^{2}$ & 0.09 & 0.38 & 0.39 & 0.10 & 0.27 & 0.31 & 0.33 & 0.41 & 0.01 & 0.17 & 0.11 & 0.16 & 0.26 \\
\hline $\mathrm{F}$ & $23.83 * * *$ & $109.22 * * * *$ & $84.91 * * *$ & $24.93 * * * *$ & $67.81 * *$ & $81.22 * * *$ & $99.40 * * *$ & $104.28 * * *$ & $1.97 * * *$ & $12.78 * * *$ & $8.44 * * *$ & $13.53 * * *$ & $16.88 * * *$ \\
\hline
\end{tabular}

First, compared to South East, Red River Delta employees typically respond more positively to co-worker support in the workplace. In other words, employees in Red River Delta may respond more easily to co-workers' support and have higher OC. This may be because a workplace in Red River Delta tends to have more collectivistic culture shared by employees, which leads them to expect colleagues to support each other. Second, compared to Red River Delta, South East employees typically respond more positively to benefit satisfaction. In other words, employees in South East may respond more easily to benefit and have higher OC. This may be because a workplace in South East tends to have more individualistic culture shared by employees, which leads them to expect the management to enrich financial and material benefit. The first difference indicates that people tend be more collectivistic in economically less developed area (i.e., Red River Delta) than in more developed area (i.e., South East). On the contrary, the second difference indicates that people are likely more individualistic in economically more developed area than in less developed area. Applying these results, we may predict that people would become less collectivistic and more individualistic as the country develops economically over time.

On the other hand, other rewards, namely fatigue, supervisor support and autonomy, show no significant difference between regions on the degree of association with OC. In other words, health controls of employees, employees' relation with the boss and job delegation towards employees are equally important for maintaining their OC in both regions. These results are not expected but at the same time are full of interesting suggestion for considering the regional cultural difference in this country. Let us remember that previous research describes Vietnamese culture as large power distance, high collectivism, maintaining face, etc. (Nguyen, 2002; Ralston et al., 1999; Truong \& Nguyen, 2002). Among them, in so far as collectivism, regional difference of correlation between co-worker support and OC in this research indicates that collectivism is weaker in South East than in Red River Delta, suggesting that people become less collectivistic as a society becomes wealthier. On the other hand, what can we consider about power distance? Our results show that there was no significant difference in the effect of supervisor support toward OC between regions, suggesting that a culture of boss- subordinate relationship, typically known as high power distance, does not change by economic development so much. This difference between supervisor and co-worker support in relation to OC may be attributed to the nature of these rewards. A culture of collectivism may be more or less common in less developed and agriculture-based society as people live and work together retaining close ties with their families (Nguyen, 2002). Accordingly, such collectivistic culture may become weaker as the society transcend economically and force them to live as business people. On the other hand, a culture of hierarchical value, which came from China as a central facet of the Confucian canon more than two thousand years ago and has penetrated through this country affecting people's way of thinking (Zhu, 2003), may not change easily.

On the other hand, more cautious explanation might be necessary for another variable which showed unexpected 
result: i.e., "autonomy" was initially expected to be stronger in association with OC in South East than in Red River Delta as it was considered to be a fragment of intrinsic rewards and become larger in its effect to OC as economy develops. However, our result shows that correlation between autonomy and $\mathrm{OC}$ was equally strong between economically different regions. This finding was not expected, yet nor is it a complete surprise given the culture of this country. Despite their high collectivistic culture, Vietnamese are known to be sometimes individualistic at work (Nakamura, 2009). These contradictive features might be because they are originally from autonomous villages, where each village people feel an intimacy and mutual support only within itself, existing quite independently from the others (Nguyen \& Aoyama, 2013). Actually, Vietnamese are known to express a strong desire for self-control and self-dependence more than Chinese saying "phepvuathua le lang (king's rule is transcended by village's regulation)" (Thang, Rowley, Quang, \& Warner, 2007, p. 121). Accordingly, the reason why no significant regional difference was found in association between autonomy and OC may be because two tendencies behind autonomy worked opposite direction and canceled out each other: i.e., (i) people became more individualistic (in the meaning of business persons in industrialized society) and came to require more autonomous work along with economic development; (ii) people became less individualistic (in the meaning of farmers in traditional isolated village society) and came to be able to bear more hierarchically controlled work styles. For reference, the latter interpretation is in line with an argument that industrialization typically accompanies socialization of employees from farmers to industrial workers (Kerr et al., 1960; Landes, 1969; Thompson, 1967).

Similar reasoning may be possible for the result of fatigue, which was initially expected to be stronger in association with OC in South East than in Red River Delta but our result shows no difference between regions. Before the analysis, we predicted that the relation between fatigue and OC may be stronger in more advanced areas as people are more individualistic and acquisitive requiring the balance of work and life. Actually, recent empirical cross-country research shows that employees from individualistic countries reported a higher perceived workload and higher turnover intentions than their counterparts in collectivistic countries while working the same number of hours (Yang et al., 2012). However, we could have considered differently, i.e., the relation might be stronger in less developed areas as laborers were less accustomed to the way of working in modern industries due to shorter period of industrialization and accordingly might be more sensitive to the stress which occurs in the process of adaptation to regularity and discipline (Kerr et al., 1960). By canceling out of these possible effects each other, it is considered that fatigue did not have meaningful effect to differentiate these regions in so far as its relation with OC.

We may perhaps further utilize this paper's results to consider appropriate allocation of industries by regions by focusing on spatial difference of collectivistic and individualistic values. Namely, industries which require more collectivistic features of employees, such as manufacturing industries which place great importance on teamwork and cooperation among employees, may be better to select Red River Delta as a place of operation. On the other hand, those which seek for more competitive attitudes of employees, such as commercial and service industries which are easier to construct payment scheme based on the employees' accomplishments, may be better to select South East. For reference, these assertions are consistent with considerations of Japanese experienced business consultants who operate in Vietnam and evaluate Vietnamese by more intuitive words such as "northern people are more suitable for manufacturing and southern people are more suitable for sales" (Sugiura, 2016; see also Hachiya, 2013; Life Style Researcher, 2015; Osato, 2015). Off course, applying the discussion above, these features may not be everlasting but would rather change as the country further develops economically over time.

Additionally, we may examine local adaptability of the management of Japanese companies in both regions. Japanese companies is sometimes considered to be a second family which encourages intensive socialization (Jackson \& Tomioka, 2004) and require managers closely involved with a work group (Whitney, 1994, p.100), even though nowadays Japanese management changes and parts from such family-like style due to economic stagnation and the influence of globalization (Haghirian, 2010). In this sense, Japanese companies may possibly have advantages to adapt themselves to Vietnamese work conditions especially in Red River Delta which leave more collectivistic culture than South East. However, we may not take an optimistic view remembering the fact that Japanese managers are typically less trusted from their subordinates than local counterparts especially for job performing ability, leadership and capability for managing subordinates (Shiraki, 2012). Accordingly, collectivistic culture of Japanese companies may not be attractive for the employees even in Red River Delta, rather, could become harmful to soundness of the management through the channel of stronger effect of peers' support towards OC in this region. Accordingly, Japanese companies may need to improve the HRM in Vietnam, especially in human relations in Red River Delta, to enhance the employees' OC by strengthening the support each other through enriched education and training for team building, localization of the management by transferring authority from Japanese expatriates to local staffs, etc. 
On the other hand, Japanese companies may face more difficulties to adapt themselves to the environment in South East because they are known to be less competitive in payment schemes than the Western and Korean companies (Toyota, 2015). Such low payment is off course partly due to low localization of the management of Japanese companies, and in this sense, it is assumed that extrinsic rewards are closely related with intrinsic rewards which have equally strong effect to OC in South East. Based on the result of this research, it is expected that Vietnamese may become more individualistic and acquisitive requiring more extrinsic rewards as the economy develops continuously in the future. Japanese companies may have to reconsider their HRM to become more attractive and fully function to induce higher OC even in more advanced future societies in Vietnam.

\section{Study Limitations and Suggestions for Future Research}

There are three significant limitations on this research. The first one is about impartiality. The sample in this research is unevenly distributed by regions: 4 companies are in Red River Delta whereas 1 company is in South East. Furthermore, employees who work for automobile and parts industries account for more than 80 percent of the sample in Red River Delta, whereas those who work for electrical parts industry account for 100 percent in South East. The fact that the sample employees are all extracted from Japanese companies and not from others also should not be overlooked. Accordingly, future research using the sample of larger volume and wider variety of industries/origins may perhaps revise our findings in this research.

The second limitation is about applicability. The regional difference in rewards-OC relationship is considered to have been molded through long and complicated history of this country such as influence of China in the northern part and the United States and the Western countries in the southern part. Accordingly, we might be lead to wrong directions if we simply apply the same methodology to other nations' cities (e.g., Beijing and Shanghai) without taking account such historical characteristics. Future research of intra-national differences is recommended to carefully take into account regional features of the sample.

The third limitation of this research is about reliability. This study used self-report data from single respondents, which may have resulted in common method bias. Future research might consider the inclusion of supervisor-rated scales to reduce common method bias and remedy the weakness of the present study design.

\section{References}

Aiken, L. S., \& West, S. G. (1991). Multiple regression: Testing and interpreting interactions. Thousand Oaks, CA: Sage.

Allen, N. J., \& Meyer, J. P. (1990). The measurement and antecedents of affective, continuous, and normative commitment to the organization. Journal of Occupational Psychology, 63(1), 1-18. http://dx.doi.org/10.1111/j.2044-8325.1990.tb00506.x

Basabe, N., \& Ros, M. (2005). Cultural dimensions and social behavior correlates: Individualism-collectivism and power distance. Revue Internationale De Psychologie Sociale, 18(1), 189-225. Retrieved from http://newunionism.net/library/workplace\%20democracy/

Berg, A. G., \& Ostry, J. D. (2011). Inequality and unsustainable growth: Two sides of the same coin? Washington, D.C.: International Monetary Fund. IMF Staff Discussion Note SDN/11/08 (8 April). Retrieved from https://www.imf.org/external/pubs/ft/sdn/2011/sdn1108.pdf

Beukhof, G., De Jong, M. J., \& Nijhof, W. J. (1998). Employee commitment in changing organization: An exploration. Journal of European Industrial Training, 22(6), 243-248. http://dx.doi.org/10.1108/03090599810224701

Boyacigiller, N., \& Adler, N. J. (1991). The parochial dinosaur: Organizational suicide in global context. Academy of Management Review, 16, 262-290. http://dx.doi.org/10.5465/AMR.1991.4278936

Caught, K., Shadur, M. A., \& Rodwell, J. J. (2000). The measurement artifact in the organizational commitment questionnaire. Psychological Reports, 87(3), 777-788. http://dx.doi.org/10.2466/pr0.2000.87.3.777

Chiang, H., Han, T., \& Chuang, J. (2011). The relationship between high-commitment HRM and knowledge-sharing behavior and its mediators. International Journal of Manpower, 32(5/6), 604-622. http://dx.doi.org/10.1108/01437721111158224

Cohen, J., \& Cohen, P. (1975). Applied multiple regression/correlation analysis for the behavioral sciences. Hillsdale, NJ: Erlbaum.

Colignon, R. A., Usui, C., Kerbo, H., \& Slagter, R. (2007). Employee commitment in US and Japanese firms in Thailand. Asian Social Science, 3(11), 16-32. Retrieved from http://digitalcommons.calpoly.edu/cgi/viewcontent.cgi?article=1051\&context=ssci_fac 
Eby, L. T., Freeman, D. M., Rush, M. C., \& Lance, C. E. (1999). Motivational bases of affective organizational commitment: A partial test of an integrative theoretical model. Journal of Occupational and Organizational Psychology, 72(4), 463-483. http://dx.doi.org/10.1348/096317999166798

Engholm, C. (1995). Doing business in the new Vietnam. Englewood Cliffs, NJ: Prentice Hall.

Fischer, R., \& Mansell, A. (2009). Commitment across cultures: A meta-analytical approach. Journal of International Business Studies, 40(8), 1339-1358. http://dx.doi:10.1057/jibs.2009.14

General Statistics Office of Vietnam. (2014). Foreign direct investment enterprises in the period of 2006-2011. Statistical Publishing House, Hanoi. from http://www.gso.gov.vn/default_en.aspx?tabid=515\&idmid=5\&ItemID=13957

General Statistics Office of Vietnam. (2016). Result of the Vietnam household living standards survey 2014. Statistical Publishing House, Hanoi. from http://www.gso.gov.vn/default_en.aspx?tabid=515\&idmid=5\&ItemID=18411

General Statistics Office of Vietnam. (2016). Statistical handbook of Vietnam 2015. Statistical Publishing House, Hanoi. Retrieved from http://www.gso.gov.vn/default_en.aspx?tabid=515\&idmid=5\&ItemID=16003

Haar, J. M., \& Spell, C. S. (2004). Programme knowledge and value of work-family practices and organizational commitment. International Journal of Human Resource Management, 15(6), 1040-1054. http://dx.doi.org/10.1080/09585190410001677304

Hachiya, K. (2013). Nanboku Vietnam jinzai no chigai (The difference of human resources between southern and northern Vietnam). Global Management Laboratory Inc. (Japanese). Retrieved from http://www.globalmgtlab.com/columns20131206.html

Hai, H. T. (2012). Factors influencing organizational commitment and intention to stay of core employees in small - medium sized companies in Hochiminh City. University of Economics Ho Chi Minh City.

Herzberg, F. (1966). Work and the nature of man. Cleveland: World Publishing.

Hoang, H. (2008). Culture and management: A study of Vietnamese cultural influences on management style (Unpublished doctoral dissertation). Capella University, Minnesota, United States.

Hofstede, G. (1980). Culture's consequence. Beverly Hills, CA: Sage Publications.

Hofstede, G. (2001). Culture's consequences (2nd ed.). Beverly Hills, CA: Sage Publications.

Hou, Y., Gao, G., Wang, F., Li, T., \& Yu, Z. (2011). Organizational commitment and creativity: the influence of thinking styles. Annals of Economics \& Finance, 12(2), 411-431. Retrieved from http://aefweb.net/aefarticles/aef120209.pdf

Jackson, K., \& Tomioka, M. (2004). The Changing face of Japanese management. London: Routledge.

Jafri, M. H. (2010). Organizational commitment and employee's innovative behavior: A study in retail sector. Journal of Management Research, 10(1), 62-68.

Japan Bank for International Cooperation. (2008). The 20th annual survey report on overseas business operations by Japanese manufacturing companies. http://www.jbic.go.jp/en/about/press/2008/1125-02/index.html.

Japan External Trade Organization. (2014). ASEAN, Nansei Asia no business kankyo wo doumiruka? Business jou no kadai wo chushin ni (What can we think about business environment in ASEAN and South West Asia? Special focus on challenges in business), April 22, 2014. (Japanese). Retrieved from https://www.jetro.go.jp/world/reports/2014/07001693.html

Kerr, C., Dunlop, J. T., Harbison, F. H., \& Myers, C. A. (1960). Industrialism and industrial man: The problems of labour and management in economic growth. Cambridge Mass.: Harvard University Press.

Kokubun, K. (2006). Globalization and industrial reallocation: How to motivate Malaysian workers. Paper presented at the 3rd International Globalization Studies Network (GSN) Conference, Universiti Kebangsaan Malaysia.

Kokubun, K. (2017). Organizational commitment and rewards in Thailand, with comparison between university graduates and others. Asian Social Science, 13(6), 1-19. https://doi.org/10.5539/ass.v13n6p1

Kokubun, K. (2017). The moderating effect of gender on the organizational commitment-rewards relationship. International Journal of Business and Management, 12(7), 1-16. https://doi.org/10.5539/ijbm.v12n7p1 
Kokubun, K. (2017). Organizational commitment-rewards relationship and its change in Japanese companies in China. International Business Research,10(7), 155-167. https://doi.org/10.5539/ibr.v10n7p155

Landes, D. S. (1969). The unbound prometheus: Technological change and industrial development in Western Europe from 1750 to the present. Cambridge: Cambridge University Press.

Life Style Researcher. (2015). Henkakukiniaru Vietnam naijukakudai to "Nippon" no kanousei (Domestic demand expansion in Vietnam under transitional period and possibility of "Japan"). TNC Monthly Report March 31, 2015, TNC Inc. (Japanese). Retrieved from http://lifestyle.tenace.co.jp/?country=vietnam

Malhotra, N., Budhwar, P., \& Prowse, P. (2007). Linking rewards to commitment: An empirical investigation of four UK call centres. International Journal of Human Resource Management, 18(12), 2095-2128. http://dx.doi.org/10.1080/09585190701695267

Maslow, A. H. (1943). A theory of human motivation. Psychological Review, 50(4), 370-396. http://dx.doi.org/10.1037/h0054346

Mercer \& Talentnet Corporation. (2015). Vietnam Reward Trends 2015-2016. Ho Chi Minh City, October 7th, 2015. Retrieved from http://36mfjx1a0yt01ki78v3bb46n15gp.wpengine.netdna-cdn.com/wp-content/uploads/2015/09/2015-VN-T otal-Remuneration-Survey-Ms-Hoa-Nguyen.pdf

Meyer, J. P., Stanley, D. J., Herscovitch, L., \& Topolnysky, L. (2002). Affective, continuous, and normative commitment to the organization: A meta-analysis of antecedents, correlates, and consequences. Journal of Vocational Behavior, 61, 20-52. http://dx.doi.org/10.1006/jvbe.2001.1842

Miao, Q., Newman, A., Sun, Y., \& Xu, L. (2013). What factors influence the organizational commitment of public sector employees in China? The role of extrinsic, intrinsic and social rewards. International Journal of Human Resource Management, 24(17), 3262-3280. http://dx.doi.org/10.1080/09585192.2013.770783

Milfont, T. L., \& Fischer, R. (2010). Testing measurement invariance across groups: Applications in cross-cultural research. International Journal of Psychological Research, 3, 111-121. Retrieved from file://C:/Users/user/Downloads/857-2261-1-PB.pdf

Mottaz, C. J. (1985). The relative importance of intrinsic and extrinsic rewards as determinants of work $\begin{array}{llll}\text { satisfaction. The } & \text { Sociological }\end{array}$ http://dx.doi.org/10.1111/j.1533-8525.1985.tb00233.x

Mowday, R. T., Porter, L. W., \& Steers, R. M. (1982). Employee-organization linkages: The psychology of commitment, absenteeism and turnover. New York, NY: Academic Press.

Nakamura, H. (2009). Circumstances and trends of direct investment in Vietnam local production and HRM of Japanese affiliated companies. Keiei Ronsyu, 74, 33-46 (Japanese). Retrieved from https://www.toyo.ac.jp/uploaded/attachment/3010.pdf

Newman, A., \& Sheikh, A. Z. (2012). Organizational commitment in Chinese small- and medium-sized enterprises: The role of extrinsic, intrinsic and social rewards. International Journal of Human Resource Management, 23(2), 349-367. http://dx.doi.org/10.1080/09585192.2011.561229

Newman, A., Thanacoody, R., \& Hui, W. (2011). The impact of employee perceptions of training on organizational commitment and turnover intentions: A study of multinationals in the Chinese service sector. International Journal of Human Resource Management, 22(8), 1765-1787. http://dx.doi.org/10.1080/09585192.2011.565667

Neyestani, M., Piran, M., Nasabi, N., Nosrati, K., \& Maidanipour, K. (2013). The necessity of organizational commitment for knowledge sharing case study: Shiraz University of Medical Sciences. Journal of Sociological Research, 4(1), 162-171. http://dx.doi.org/10.5296/jsr.v4i1.2921

Nguyen, N. T. D., \& Aoyama, A. (2013). Exploring cultural differences in implementing international technology transfer in the case of Japanese manufacturing subsidiaries in Vietnam. Contemporary Management Research, 9(1), 13-34. http://dx.doi.org/10.7903/cmr.10338

Nguyen, T. N., Mai, K. N., \& Nguyen, P. V. (2014). Factors affecting employees' organizational commitment-A study of banking staff in Ho Chi Minh City, Vietnam. Journal of Advanced Management Science, 2(1), 7-11. http://dx.doi.org/10.12720/joams.2.1.7-11

Nguyen, V. P. (2002). Organizational culture in Vietnam. Tia Sang Journal, 25, 117-127.

Nunnally, J. C. (1978). Psychometric theory. New York: McGraw-Hill. 
O'Reilly, C. A., \& Caldwell, D. F. (1980). Job choice: The impact of intrinsic and extrinsic factors on subsequent satisfaction and commitment. Journal of Applied Psychology, 65(5), 559-565. http://dx.doi.org/10.1037/0021-9010.65.5.559

Osato, K. (2015). Vietnam keizaijijo to business kankyo: Vietnam nanbu wo chushinni (Economic condition and business environment in Vietnam: Focusing on southern part of Vietnam). Japan External Trade Organization, September 25, 2015. (Japanese). Retrieved from http://www.sitc.co.jp/file/JETRO.pdf

Peyyer, C., Jordan, C., Firms, I., \& Travaglione, A. (2010). Predicting turnover intentions. Management Research Review, 33(9), 911-923. http://dx.doi.org/10.1108/01409171011070323

Pham, L., \& Pham, L. (2016). The effects of job satisfaction and organizational commitment on intention to stay: Case study at the universities, colleges in Bac Lieu City, Bac Lieu Province. Paper presented at The 10th International Days of Statistics and Economics, Prague, September 8-10, 2016. Retrieved from https://msed.vse.cz/msed_2016/article/138-Pham-Lan-paper.pdf

Pham, T. H. N. (2011). Communicating with Vietnamese in intercultural contexts: Insights into Vietnamese values. Vietnam: Educational Publishing House.

Phipps, S. T., Prieto, L. C., \& Ndinguri, E. N. (2013). Understanding the impact of employee involvement on organizational productivity: The moderating role of organizational commitment. Journal of Organizational Culture, Communication and Conflict, 17(2), 107.

Porter, L. W., \& Lawler, E. E. (1968). Managerial attitudes and performance. Homewood, IL: Dorsey Press.

Quang, T., \& Vuong, N. T. (2002). Management styles and organisational effectiveness in Vietnam. Research and Practice in Human Resource Management, 10, 36-55. Retrieved from https://rphrm.curtin.edu.au/2002/issue2/vietnam.html

Ralston, D. A., Holt, D. A., Terpstra, R. H., \& Yu, K. C. (1997). The impact of national culture and economic ideology on managerial work values: A study of the United States, Russia, Japan, and China. Journal of International Business Studies, 28, 177-208.

Ralston, D. A., Holt, D. H., Terpstra, R. H., \& Kai-Cheng, Y. (2008). The impact of national culture and economic ideology on managerial work values: A study of the United States, Russia, Japan, and China. Journal of International Business Studies, 39(1), 8-26.

Ralston, D. A., Nguyen, V. T., \& Napier, N. K. (1999). A comparative study of the work values of north and south Vietnamese managers. Journal of International Business Studies, 30(4), 655-672. http://dx.doi.org/10.1057/palgrave.jibs.8490097

Shiraki, M. (2012). Nihon Kigyo no globalization to kaigaihakensha: Asia no genchi staff niyoru joshihyoka karano kento (Japanese companies' globalization and overseas expatriates: Examination by local staffs' evaluation towards supervisors in Asia). Nihon Rodo Kenkyu Zasshi, 623, 5-16. (Japanese) Retrieved from http://www.jil.go.jp/institute/zassi/backnumber/2012/06/pdf/005-016.pdf

Steers, R. M. (1977). Antecedents and outcomes of organizational commitment. Administrative Science Quarterly, 22(1), 46-56. http://dx.doi.org/10.2307/2391745

Sugiura, N. (2016). Hokubu to Nanbu no Vietnam jinkishitsu no chigai to management no ryuiten (Difference in Vietnamese characters between northern and southern areas and points to be cared for management). My Best Pro OSAKA. (Japanese). Retrieved from http://mbp-osaka.com/leapbridge-vj/column/28359/

Than, V. D., Pham, C. H., \& Pham, L. (2016). Job stress, involvement, satisfaction and performance of employees in garment 10 corporation in Vietnam. International Journal of Financial Research, 7(3), 96-109. http://dx.doi.org/10.5430/ijfr.v7n3p96

Thang, L., Rowley, C., Quang, T., \& Warner, M. (2007). What extent can management practices be transferred between countries? The case of human resource management in Vietnam. Journal of World Business, 42(1), 113-127. http://dx.doi.org/10.1016/j.jwb.2006.11.005

Thompson, E. P. (1967). Time, work-discipline, and industrial capitalism. Past and Present, 38(1), 56-97. http://dx.doi.org/10.1093/past/38.1.56

Toyota, E. (2015). Tokubetsu koen: Nikkeikigyotou niokeru Vietnam deno jinzai ikusei (Special lecture: Human Resource Development in Japanese and other companies in Vietnam). AIBS Journal, 9, 39-43. (Japanese) Retrieved from file:///C:/Users/user/Downloads/11200137.pdf

Triandis, H. C. (1995). Individualism and collectivism. Boulder, CO: Westview. 
Truong, Q., \& Nguyen, T. V. (2002). Management styles and organizational effectiveness in Vietnam. Research and Practice in Human Resource Management, 10(2), 36-55. Retrieved from https://rphrm.curtin.edu.au/2002/issue2/vietnam.html

U.S. Department of State. (2014). Investment Climate Statement, June 2014. Retrieved from https://www.state.gov/documents/organization/229305.pdf

Vuong, T. M. H., \& Yokoyama, K. (2011). Is Vietnam attractive to Japanese FDI comparing to Thailand and China? An attribute-based and holistic analysis. Ritsumeikan Annual Review of International Studies, 10, 19-46. Retrieved http://www.ritsumei.ac.jp/acd/cg/ir/college/bulletin/e-vol.10/02Vuong\%20Yokoyama.pdf

Wasti, S. A. (1998). Cultural barriers in the transferability of Japanese and American human resources practices to developing countries: the Turkish case. International Journal of Human Resource Management, 9(4), 608-631. http://dx.doi.org/10.1080/095851998340928

Whitney, R. (1994). Business systems in Asia: Firms, markets and societies. London, Newbury Park: Sage publications.

World Bank. (2017). Overview. Apr 13, 2017 (last updated). Retrieved from http://www.worldbank.org/en/country/vietnam/overview

Yan, Y. X. (2009). The Individualization of Chinese Society. Oxford: Berg.

Yang, L. Q. et al. (2012). Individualism-collectivism as a moderator of the work demands-strains relationship: A cross-level and cross-national examination. Journal of International Business Studies, 43(4), 424-443. http://dx.doi:10.1057/jibs.2011.58

Yu, J., \& Meyer-Ohle, H. (2008). Working for Japanese corporations in China: A qualitative study. Asian Business and Management, 7(1), 33-51. http://dx.doi.org/10.1057/palgrave.abm.9200250

Zhang, J. (2003). Nikkei kigyo no jinjiromukanri to chinginmondai: Kawaru Chugokujin no ishiki to kawaranu Nihongatakeiei (The labor management of Japanese companies and the problems of its wage system: The changing concepts of Chinese and the changeless Japanese management). Asia Market Review, 15(10), 34-36. (Japanese) Retrieved from http://chasechina.jp/reports/chinabiz/resources/401.html

Zhu, Y. (2003). Culture and management in Vietnam. In M. Warner (Ed.), Culture and Management in Asia (pp. 249-263). London and New York: Routledge Curzon. 


\section{Appendix A}

\section{Demographic Inofrmation}

\begin{tabular}{|c|c|c|c|c|c|c|c|c|c|c|}
\hline & \multicolumn{2}{|c|}{ Gender } & \multirow{2}{*}{ Total } & \multicolumn{5}{|c|}{ Age } & \multirow{2}{*}{ Total } & \\
\hline & Male & Female & & $\begin{array}{c}\text { Belowr } 20 \\
\text { years old }\end{array}$ & $20-29$ & $30-39$ & $40-49$ & $\begin{array}{c}50 \text { years old } \\
\text { and above }\end{array}$ & & \\
\hline \multirow{2}{*}{$\begin{array}{c}\text { Red River } \\
\text { Delta }\end{array}$} & 1,591 & 773 & 2,364 & 4 & 1,579 & 696 & 77 & 8 & 2,364 & \\
\hline & $67.3 \%$ & $32.7 \%$ & $100.0 \%$ & $0.2 \%$ & $66.8 \%$ & $29.4 \%$ & $3.3 \%$ & $0.3 \%$ & $100.0 \%$ & \\
\hline \multirow{2}{*}{ South East } & 142 & 441 & 583 & 14 & 472 & 92 & 5 & 7 & 590 & \\
\hline & $24.4 \%$ & $75.6 \%$ & $100.0 \%$ & $2.4 \%$ & $80.0 \%$ & $15.6 \%$ & $0.8 \%$ & $1.2 \%$ & $100.0 \%$ & \\
\hline \multirow{4}{*}{ Total } & 1,733 & 1,214 & 2,947 & 18 & 2,051 & 788 & 82 & 8 & 2,947 & \\
\hline & $58.8 \%$ & $41.2 \%$ & $100.0 \%$ & $0.6 \%$ & $69.6 \%$ & $26.7 \%$ & $2.8 \%$ & $0.3 \%$ & $100.0 \%$ & \\
\hline & \multicolumn{5}{|c|}{ Tenure } & \multirow{2}{*}{ Total } & \multicolumn{2}{|c|}{ Turnover experience } & & \\
\hline & Below 2 year & $2-5$ year & $6-9$ years & $10-19$ years & $\begin{array}{c}20 \text { years and } \\
\text { above }\end{array}$ & & $\begin{array}{c}\text { Have } \\
\text { experience }\end{array}$ & $\begin{array}{l}\text { Have no } \\
\text { experience }\end{array}$ & Total & \\
\hline Red River & 16 & 125 & 1,128 & 634 & 461 & 2,364 & 927 & 1,437 & 2,364 & \\
\hline Delta & $0.7 \%$ & $5.3 \%$ & $47.7 \%$ & $26.8 \%$ & $19.5 \%$ & $100.0 \%$ & $39.2 \%$ & $60.8 \%$ & $100.0 \%$ & \\
\hline \multirow{2}{*}{ South East } & 120 & 137 & 182 & 124 & 20 & 583 & 514 & 69 & 583 & \\
\hline & $20.6 \%$ & $23.5 \%$ & $31.2 \%$ & $21.3 \%$ & $3.4 \%$ & $100.0 \%$ & $88.2 \%$ & $11.8 \%$ & $100.0 \%$ & \\
\hline \multirow{4}{*}{ Total } & 136 & 262 & 1,310 & 758 & 481 & 2,947 & 1,441 & 1,506 & 2,947 & \\
\hline & $4.6 \%$ & $8.9 \%$ & $44.5 \%$ & $25.7 \%$ & $16.3 \%$ & $100.0 \%$ & $48.9 \%$ & $51.1 \%$ & $100.0 \%$ & \\
\hline & \multicolumn{8}{|c|}{ Educational background } & \multirow[b]{2}{*}{ Total } & \\
\hline & $\begin{array}{c}\text { Lower } \\
\text { Secondary } \\
\text { School }\end{array}$ & $\begin{array}{c}\text { Upper } \\
\text { Secondary } \\
\text { School }\end{array}$ & $\begin{array}{l}\text { Specialized } \\
\text { College }\end{array}$ & $\begin{array}{c}\text { College/ } \\
\text { Vocational }\end{array}$ & University & $\begin{array}{c}\text { Graduate } \\
\text { School }\end{array}$ & $\begin{array}{c}\text { In the middle } \\
\text { of school } \\
\text { years }\end{array}$ & Others & & \\
\hline Red River & 41 & 1,233 & 255 & 412 & 360 & 15 & 28 & 20 & 2,364 & \\
\hline Delta & $1.7 \%$ & $52.2 \%$ & $10.8 \%$ & $17.4 \%$ & $15.2 \%$ & $0.6 \%$ & $1.2 \%$ & $0.8 \%$ & $100.0 \%$ & \\
\hline \multirow{2}{*}{ South East } & 60 & 355 & 14 & 64 & 77 & 2 & 8 & 3 & 583 & \\
\hline & $10.3 \%$ & $60.9 \%$ & $2.4 \%$ & $11.0 \%$ & $13.2 \%$ & $0.3 \%$ & $1.4 \%$ & $0.5 \%$ & $100.0 \%$ & \\
\hline \multirow{4}{*}{ Total } & 101 & 1,588 & 269 & 476 & 437 & 17 & 36 & 23 & 2,947 & \\
\hline & $3.4 \%$ & $53.9 \%$ & $9.1 \%$ & $16.2 \%$ & $14.8 \%$ & $0.6 \%$ & $1.2 \%$ & $0.8 \%$ & $100.0 \%$ & \\
\hline & \multicolumn{3}{|c|}{ Marital status } & & \multicolumn{2}{|c|}{ Department } & & \multicolumn{2}{|c|}{ Position } & \\
\hline & Single & Married & Others & Total & $\begin{array}{c}\text { Direct } \\
\text { department }\end{array}$ & $\begin{array}{l}\text { Indirect } \\
\text { department }\end{array}$ & Total & $\begin{array}{l}\text { Managerial } \\
\text { position }\end{array}$ & $\begin{array}{c}\text { Non- } \\
\text { managerial } \\
\text { position }\end{array}$ & Total \\
\hline Red River & 605 & 1,737 & 22 & 2,364 & 1,821 & 543 & 2,364 & 141 & 2,223 & 2,364 \\
\hline Delta & $25.6 \%$ & $73.5 \%$ & $0.9 \%$ & $100.0 \%$ & $77.0 \%$ & $23.0 \%$ & $100.0 \%$ & $6.0 \%$ & $94.0 \%$ & $100.0 \%$ \\
\hline \multirow{2}{*}{ South East } & 328 & 250 & 5 & 583 & 367 & 216 & 583 & 45 & 538 & 583 \\
\hline & $56.3 \%$ & $42.9 \%$ & $0.9 \%$ & $100.0 \%$ & $63.0 \%$ & $37.0 \%$ & $100.0 \%$ & $7.7 \%$ & $92.3 \%$ & $100.0 \%$ \\
\hline \multirow{4}{*}{ Total } & 933 & 1,987 & 27 & 2,947 & 2,188 & 759 & 2,947 & 186 & 2,761 & 2,947 \\
\hline & $31.7 \%$ & $67.4 \%$ & $0.9 \%$ & $100.0 \%$ & $74.2 \%$ & $25.8 \%$ & $100.0 \%$ & $6.3 \%$ & $93.7 \%$ & $100.0 \%$ \\
\hline & \multicolumn{4}{|c|}{ Industry } & \multirow[b]{2}{*}{ Total } & & & & & \\
\hline & Automobile & $\begin{array}{l}\text { Automobile } \\
\text { parts }\end{array}$ & $\begin{array}{l}\text { Electrical } \\
\text { parts }\end{array}$ & Others & & & & & & \\
\hline Red River & 1,481 & 461 & 0 & 422 & 2,364 & & & & & \\
\hline Delta & $62.6 \%$ & $19.5 \%$ & $0.0 \%$ & $17.9 \%$ & $100.0 \%$ & & & & & \\
\hline \multirow{2}{*}{ South East } & 0 & 0 & 583 & 0 & 583 & & & & & \\
\hline & $0.0 \%$ & $0.0 \%$ & $100.0 \%$ & $0.0 \%$ & $100.0 \%$ & & & & & \\
\hline Total & 1,481 & 461 & 583 & 422 & 2,947 & & & & & \\
\hline 10tala & $50.3 \%$ & $15.6 \%$ & $19.8 \%$ & $14.3 \%$ & $100.0 \%$ & & & & & \\
\hline
\end{tabular}

\section{Copyrights}

Copyright for this article is retained by the author(s), with first publication rights granted to the journal.

This is an open-access article distributed under the terms and conditions of the Creative Commons Attribution license (http://creativecommons.org/licenses/by/4.0/). 